\title{
Л.Ф. Хабибуллина
}

\section{СИМВОЛИКА РАСТЕНИЙ В РАССКАЗЕ Д.Г. ЛОУРЕНСА «АНГЛИЯ, МОЯ АНГЛИЯ» В КОНТЕКСТЕ ПРОБЛЕМЫ АНГЛИЙСКОСТИ}

\begin{abstract}
В статье рассматривается рассказ Д.Г. Лоуренса «Англия, моя Англия» с точки зрения «растительной» символики. К моменту создания рассказа (1915) в английской литературе активно разрабатывается символический национальный «растительный» код. До середины XIX-начала XX в. этот процесс носил случайный, спонтанный характер, был связан с усилиями отдельных авторов, прежде всего поэтов. В начале ХХ в., когда тема заката империи актуализируется в английской литературе, стремление создать общий символический код уходящего мира становится более очевидным. Анализируемый рассказ наиболее показателен с этой точки зрения. В нем с помощью растительной символики создается типология английских характеров и анализируется предвоенная ситуация в стране.

Ключевые слова: английскость, Д.Г. Лоуренс, кельтский, саксонский, нормандский компонент, растительная символика, образ розы.
\end{abstract}

Рассказ Д.Г. Лоуренса «Англия, моя Англия» (1915) привлекал внимание отечественных литературоведов лишь косвенно, но, на наш взгляд, ему принадлежит одна из заметных ролей в формировании представления об «английскости» в литературе XX в. В английском литературоведении заметен анализ Р. Эббэтсона (Ebbatson), который в книге An Imaginary England: Nation, Landscape and Literature, 1840-1920 (2005) рассматривает (и пересматривает) с точки зрения английскости произведения братьев Теннисон, Руперта Брука, Эдварда Томаса, Дэвида Лоуренса, завершая работу сопоставительным анализом двух издательских версий рассказа «Англия, моя Англия» в ракурсе эдвардианского фольклорного возрождения [1].

Отдельные компоненты концепции английскости начинают формироваться задолго до ХХ в. Одна из ведущих ролей здесь принадлежит, как нам представляется, исследованию разнообразия национальных типов на территории Англии и их влияния на английскую культуру, основу которому положил Мэтью Арнольд, считающийся многими авторитетными исследователями проблемы основоположником концепции английскости $[2,3,4]$. Мэтью Арнольд считал, что противоречивость национального характера англичан связана с сочетанием кельтских, англосаксонских (германских) и нормандских черт характера. М. Арнольд создает книгу «Об изучении кельтской литературы» (1893), поводом к написанию которой послужило его недовольство «филистерским» духом современной английской культуры и восхищение древней культурой кельтов, ставшее причиной насмешек над ним в критике. Говоря о необходимости изучения кельтской культуры, критик часто сравнивает греческую и кельтскую культуры [5. Р. 11, 32, 168], отмечает преимущества кельтской поэзии перед германской [Ibid. P. 140-145]. Арнольд считал, что «германский дух» дает англичанам «сочетание уравновешенности и че- 
стности», трудолюбие, упорство, верность природе (обеспечивает успехи в области пластических искусств), но и заурядность, обыденность, грубость. «Кельтские» черты характера - чувствительность, одухотворенность, непокорность, женственность. Эти черты в первую очередь способствуют развитию искусства, особенно поэзии. Соединение кельтских и германских черт ведет к успехам в живописи и порождает особый тип религиозности, свойственный англичанам (внутренне эмоциональная, вера англичан внешне рациональна). «Нормандский» дух проявился в энергичности и находчивости (что ведет к успехам в ораторском искусстве), но и в высокомерии и жестокости» [6]. Лекции Арнольда породили многочисленные дискуссии и стали, вероятно, одним из первых шагов в направлении тех широких исследований английскости, которые предпринимаются в XX в.

Определение Арнольдом роли кельтского компонента в английской культуре приводит к актуализации кельтского мифа, с одной стороны, и попытке выяснения внутреннего символического смысла английского национального характера - с другой. Идеи Арнольда подхватывают представители модернистской литературы. В литературе, близкой к модернизму, полемика с викторианской эпохой приводила к трансформации не столько национальной проблематики, сколько форм ее выражения. Например, в творчестве Д.Г. Лоуренса, Р. Олдингтона тема Англии была одной из ведущих, но глубокое осознание кризиса викторианских ценностей заставляет этих авторов в основном анализировать их крушение в современном обществе, что ведет и к отображению кризиса английских национальных ценностей в целом, так как они осознаются этими авторами в неразрывной связи с викторианством. Так, в романе Р. Олдингтона «Смерть героя» кризис викторианских ценностей становится главной темой произведения. Смерть главного героя, Джорджа Уинтерборна, объясняется в первую очередь его стремлением выйти из ситуации кризиса. Роман идеологически чрезвычайно близок к рассказу Лоуренса, отличаясь лишь способами выражения и смысловыми оттенками, вытекающими из системы ценностей каждого из авторов. Д.Г. Лоуренс относится к тем авторам, которые много размышляли о кризисе в Великобритании в до- и послевоенные годы, но рассматривали этот кризис не столько в социальном плане, сколько в культурном. Благодаря таким авторам, как Р. Киплинг, Д. Лоуренс, в начале XX в. разрабатывается символический «язык» английскости, который позволяет создать мифологию нации в кризисный период. Значение символического языка в творчестве Лоуренса привлекало внимание исследователей в целом, на примере его крупных произведений [7, 8 , 9], однако символика растений в рассказе «Англия, моя Англия» не рассматривалась.

В рассказе Д. Лоуренса «Англия, моя Англия» воссоздается одновременно жизнеподобная (действие привязано к периоду до Первой мировой войны) и символическая картина английской жизни, где концепция национального характера предстает уже в мифологизированном варианте с характерным для модернизма акцентированием культурного компонента как имманентного свойства национального характера. 
На первый взгляд Лоуренс создает вполне реалистическую картину предвоенной жизни английской семьи, описывая ситуацию, в которой молодые супруги, Эгберт и Уинифрид, не смогли справиться с бытовыми проблемами и, несмотря на взаимную любовь, потеряли свое семейное счастье. Образная система рассказа воплощает вполне узнаваемые типы представителя нежизнеспособной аристократии (Эгберт) и мощной буржуазии (отец Уинифрид, Годфри Маршалл). Эгберт, обладая несомненными достоинствами (красота, внутренняя сила, любовь к английской старине, культуре), оказывается не в силах содержать семью, отстраняется от жены и детей и, в конце концов, ощущая свою ненужность, отправляется на войну (речь идет о Первой мировой войне) и погибает там. Роль защитника семьи достается его тестю, уверенному в себе, способному поддержать дочь и внуков. Изображение конфликта между этими группами далеко не новость в английской литературе, достаточно вспомнить произведения Дж. Голсуорси или других представителей английского реализма. Отличие произведения Лоуренса в способе подачи ситуации, в том, что конфликт переведен из социально-бытового в символический план, что позволяет писателю выйти за пределы бытового (неспособность Эгберта содержать семью) и исторического (проблемы «потерянного поколения», нелепо гибнущего во время Первой мировой войны) конфликтов и продемонстрировать неизбежность ухода в прошлое целого типа людей, представлявших некогда неотъемлемую часть Англии, ее культуры, ее сущности. Одним из способов создания мифологизированной картины мира в творчестве Д.Г. Лоуренса становится широкое использование «растительной» символики, значение которой для писателя отмечает большинство исследователей [7. Р. 411-413; 8. С. 17] .

Растительные образы предстают в произведении двояко: во-первых, непосредственно как часть английской природы, древняя Англия, воплощенная в образе сада: «...белые и лиловые водосборы, огромные яркие маки, алые, с черными прожилками: статные желтые коровяки - весь этот пламенеющий сад, который и тысячу лет назад уже был садом, возделанным в лощине среди змеиных пустошей. Старина, седая старина!» [9] (см. «...purple and white columbines, and great oriental red poppies with their black chaps and mulleins tall and yellow, this flamy garden which had been a garden for a thousand years, scooped out in the little hollow among the snake-infested commons. He had made it flame with flowers, in a sun cup under its hedges and trees. So old, so old a place!» [11]). Образ Англии-сада, который одновременно является Старой Англией, «Англией деревушек и йоменов», поддерживается на протяжении всего рассказа и противопоставляется Лондону. Образ сада обрамляет рассказ, возвращаясь в финале практически теми же образами: «Еще этим летом сад заблистает лазурью воловиков, пурпуром огромных маков; мягко закача-

\footnotetext{
${ }^{1}$ Например: «В поэтике Лоренса решающую роль играет символическое использование образов цветов (недолговечной розы, вечно цветущего зеленого остролиста, хризантемы - символа скорби, печали, увядания, смерти, полевой маргаритки - символа хрупкости и уязвимости, белого шиповника, передающего целую гамму разнообразных внутренних состояний героя от мук неразделенной любви до упоения счастьем) и деревьев, отражающих веками сложившуюся традицию, согласно которой они являются естественными символами жизненного процесса, стимулирующими такие черты, как жизнеспособность и умение выстоять в самых тяжких ситуациях» [8. С. 17].
} 
ют станом на ветру пушистые коровяки, его любимцы, а ночью, под уханье филина, жимолость будет струить свой аромат, сладостный, точно воспоминание» [10] («This summer still it would flame with blue anchusas and big red poppies, the mulleins would sway their soft, downy erections in the air:he loved mulleins: and the honeysuckle would stream out scent like memory, when the owl was whooing» [11]). Во-вторых, символизм растений проявляется в характеристике главных героев через ключевые образы художественного мира Лоуренса - Дерева и Розы [9. С. 19].

Символика цветка. На протяжении всего рассказа противопоставляются два английских типа. Первый, представленный образом главного героя рассказа, Эгберта, вбирает в себя одновременно два национальных компонента нормандский («синие острые глаза - глаза викинга» [10]), для которого характерны аристократизм, высокомерие, закрытость, и кельтский, который характеризуется артистизмом, народностью, органической связью с природой: «Эгберт же был прирожденной розой. Поколения породистых предков наградили его пленительной и непринужденной пылкостью. Он не блистал познаниями или способностями, пускай хотя бы к «сочинительству», нет. Но в музыке его голоса, в движениях гибкого тела, в упругости мускулов и блеске волос, в чистой, с горбинкой, линии носа и живости синих глаз было не меньше поэзии, чем в стихах» [10] («And Egbert was a born rose. The age-long breeding had left him with a delightful spontaneous passion. He was not clever, nor even 'literary'. No, but the intonation of his voice, and the movement of his supple, handsome body, and the fine texture of his flesh and his hair, the slight arch of his nose, the quickness of his blue eyes would easily take the place of poetry» [11]). Система ассоциаций, связанная с образом Эгберта, - это юг, аристократизм, музыка, танец моррис, свобода, сталь, роза.

Роза символизирует одновременно и аристократизм, и культуру, а также неприспособленность к жизни, характерные для представителей интеллектуальной среды периода начала ХХ в.: «...этот баловался живописью, тот пробовал сочинять или лепить, третий музицировал» [10] («...tampering with the arts, literature, painting, sculpture, music» [11]).

Еще одна «аристократическая» - ассоциация «полевые лилии, кои не утруждаются, не прядут» [10] (буквально: «Her mother once said to her, with that characteristic touch of irony: 'Well, dear, if it is your fate to consider the lilies, that toil not, neither do they spin, that is one destiny among many others, and perhaps not so unpleasant as most. Why do you take it amiss, my child?'» [11]) - возникает в разговоре об Эгберте членов его семьи. Библейская цитата, произнесенная с иронией тещей героя, активизирует аристократическую символику в сниженном варианте: «...этот цветок уже давно вымахал в полный рост, и она не хочет тратить жизнь на то, чтобы созерцать его в расцвете его красоты» [10] («But as for that other tall, handsome flower of a father of theirs, he was full grown already, so she did not want to spend her life considering him in the flower of his days» [11]). Эгберт, не берущий на себя ответственность за семью, стремящийся жить свободно, «как лилии полевые», не имеет связи с практической деятельностью, неспособен противостоять жизненным проблемам. Его вина ярче всего проявляется в сюжете с ранением дочери, которое происходит от небрежности отца, сюжет вины завершается закономерной 
гибелью персонажа на войне, ставшей венцом его неприспособленности к реальной жизни. Эта временность, недолговечность постоянно подчеркивается в образе Эгберта: «Он был как садовый цветок, который трепещет на ветру жизни, а потом осыпается, словно его и не было» [10].

Тем не менее этот образ противоречив. Жена главного героя, Уинифрид, после травмы дочери находит утешение в римской католической церкви, которая противопоставляется Эгбертовой тоске «по старым богам», воплощенной в символическом образе змеи: «...таинство кровавых жертвоприношений - все, утраченной ныне силы, ощущения первобытных обитателей этих мест, чьими страстями воздух был насыщен с тех стародавних времен, когда еще не приходили римляне» [10]. Так намечается еще одна система противопоставлений: огонь - холод, смерть - жизнь, церковь - древняя вера: «Точно языческий идол, осиянный светом, он был призван сюда ей на погибель светозарный идол жизни, готовый торжествовать победу» [10]. В этом противопоставлении, напротив, подчеркивается жизненная сила Эгберта, сила древней Англии. Поддерживает образ отца и любовь его дочери, Джойс, чья система символов - воздух, белый полевой цветок и «вакхическая отвага», воспринятая от Эгберта. Эта любовь не зависит от отношения к герою остальных персонажей рассказа, она дается ему, невзирая на его виновность в увечье дочери, как природный, естественный дар, как и все в его жизни.

Сближение аристократического компонента с народным, а также с компонентом культуры является на тот момент новым для английской литературы и воплощает тот комплекс ценностей, который наиболее явно уходит в прошлое, и становится частью «старой Англии». «Цветочная» символика используется для обозначения аристократических ценностей и ценностей культуры (фольклора). Недолговечность и красота цветка обозначают исчезновение этой системы ценностей. Образ Эгберта становится воплощением всех этих уходящих качеств и поэтому вызывает симпатию, как и они сами, но эти же качества предопределяют его гибель.

Символика дерева. Жена Эгберта, Уинифрид воплощает саксонский компонент: «...румяная, крепкая, с какой-то грубоватой истовой основательностью, налитая здоровьем, как ветка боярышника» [10] («...ruddy, strong, with a certain crude, passionate quiescence and a hawthorn robustness» [11]). Облик Уинифрид последовательно ассоциируется с кустарником: «Она двигалась со сдержанной грацией, как если бы куст, весь в пунцовом цвету, пришел в движение» [10]. Эта ассоциация поддерживается и рядом «ореховых» сравнений: Волосы у нее были ореховые, кудрявые, все в тугих завитках. У нее и глаза были ореховые, ясные, словно у птицы малиновки» [Там же] (см.: «Her hair was nut-brown and all in energic curls and tendrils. Her eyes were nut-brown, too, like a robin's for brightness» [11]). Таков же облик всей еe ceмьи: «Отец и три дочери, плотно сбитые, полнокровные, были исконным порождением английской земли, как остролист или боярышник. Культура была привита им извне - так, наверное, можно привить садовую розу на куст терновника. Она принялась, как ни странно, но кровь, текущая в их жилах, от этого не изменилась» [10] («The girls and the father were strong-limbed, thick-blooded people, true English, as holly-trees and hawthorn are English. Their culture was grafted on to them, as one might perhaps graft a common pink rose on 
to a thornstem. It flowered oddly enough, but it did not alter their blood» [11]). Представители семьи Уинифрид, особенно отец, даются через целый ряд «древесных» сравнений: «Ее фамильное дерево принадлежало к тому жизнестойкому виду растительности, чье назначение - тянуться вверх и уповать на лучшее» $[10]$ («Her family tree was a robust vegetation that had to be stirring and believing» [11]). Ее отец «хранил в себе своеобразную веру - веру терпкую, точно сок неистребимого живучего дерева. Просто веру, слепую и терпкую, - так сок в дереве слеп и терпок и все же с верой пробивается вверх, питая собою рост. Возможно, он был не очень разборчив в средствах, но ведь дерево не очень разбирается в средствах, когда в стремлении выжить продирается к месту под солнцем сквозь чащобу других деревьев» [10] («In a dark and unquestioning way, he had a sort of faith: an acrid faith like the sap of some not-to-be-exterminated tree. Just a blind acrid faith as sap is blind and acrid, and yet pushes on in growth and in faith. Perhaps he was unscrupulous, but only as a striving tree is unscrupulous, pushing its single way in a jungle of others» [11]).

Такая вера определяется Лоуренсом как единственный способ выживания. Годфри Маршалл постоянно определяется через понятие «сила»- «сила цельной натуры». Кроме того, он ассоциируется с огнем: «...горел, дымился в нем древний факел родительской богоподобной власти» [10] («...still burning in him, the old smoky torch or paternal godhead» [11]). Эта сила и отцовская власть выступают в рассказе как естественное порождение английской почвы. Именно отец в рассказе поддерживает семью дочери, является ее опорой, берет на себя те функции, которые главный герой взять не в состоянии. Противопоставление двух мужчин, двух типов личности, с одной стороны, подчеркивает неспособность Эгберта переносить тяготы реальной жизни, с другой - неспособность родителей Уинифрид и отчасти ее самой принять природу ее мужа.

Существенно, что в отличие от многих писателей Лоуренс не представляет буржуазию, которую очевидно воплощает семья Уинифрид, как нечто чуждое Англии, как внешний, уродующий ее элемент. «Древесная» символика позволяет рассмотреть этот тип людей тоже как плоть от плоти породившей их земли. Женские образы у Лоуренса традиционно воплощают природную мудрость, однако в этом рассказе образ Уинифрид противоречив. Известны антихристианские взгляды писателя, и, связывая героиню с католической церковью, он подчеркивает ее отгороженность от жизни, противопоставляя главному герою с его связью с английской древностью и языческими богами. Таким образом, оба типа укоренены в английской почве, но испытания, выпавшие на долю героя (увечье дочери, разрыв с семьей, война), оказываются непосильными для его хрупкой природы, и его уход из жизни демонстрирует уход в прошлое важной части английского мира.

Д.Г. Лоуренс - один из тех авторов, которые начинают отказываться от социальных определений национальных характеров и принимают участие в создании системы символов, закрепленной за английским, делая очередной шаг к созданию национального мифа (см.: [12]). Растительная символика становится одной из важнейших в английском национальном мифе, учитывая то, насколько глубоко осознается ценность природы, пейзажа в культуре Англии. Такой тип символизации становится важнейшим признаком укорененно- 
сти героя в английской почве, а сама система символов создает мифологизированный образ Англии как древней земли, чьи тайны остаются непостижимыми для человека.

\section{Литература}

1. Ebbatson R. An Imaginary England: Nation, Landscape and Literature, 1840-1920. Ashgate, 2005. $278 \mathrm{p}$.

2. Gikandi S. The Ghost of Matthew Arnold: Englishness and the Politics of Culture// Nineteenth-Century Contexts. Vol. 29. Nos. 2-3, June / September 2007. P. 187-199.

3. Leerssen J. Englishness, Ethnicity and Matthew Arnold // European Journal of English Studies. Vol. 10. No. 1. April, 2006. P. 63-79.

4. Kelleher, J. 'Matthew Arnold and the Celtic Revival'. Perspectives of Criticism / Ed. Harry Levin. Cambridge, MA: Harvard University Press, 1950. P. 197-221.

5. Arnold M. On the study of Celtic literature. Lnd.: Smith, Elder and Co, 1867. 181 p. https://books.google.co.uk/books?id=hysCAAAAQAAJ\&printsec=frontcover\&hl=ru\#v=onepage\&q\& $\mathrm{f}=$ false

6. Соколова Н. Викторианец об англичанах: к проблеме осмысления национальной идентичности в контексте эпохи // Проблемы идентичности, этноса, гендера в культуре и литературах Старого и Нового Света / под ред. Ю.В. Стулова. Минск, 2004. С. 54-62.

7. Rivers B. Winter-Crack Trees: Botanical Symbolism and D.H. Lawrence's 1914 Revisions of Odour of Chrysanthemums // Notes and Queries. 2012. № 59 (3). P. 411-413. https: //nq.oxfordjournals.org/content/59/3/411.full.pdf + html?sid=951 faddd-e14c-4d53-a94e-153168d38250 (дата обращения: 25.10.2016).

8. Антонова К.Н. Художественный мир прозы Д.Г. Лоренса 1910-х годов: автореф. дис. ... канд. филол. наук. СПб., 2011. 24 с.

9. Абелян М.К. Функционирование мифологических образов в творчестве Дэйвида Герберта Лоренса: автореф. дис. ... канд. филол. наук. Воронеж, 2012. 24 с.

10. Лоуренс Д.Г. Англия, моя Англия / пер. с англ. Л. Ильинской. URL: http:// lib.ru/INPROZ/ CHATER/r_england.txt (дата обращения: 25.04.2010).

11. Lawrence D. $\mathrm{H}$. England, My England // https://ebooks.adelaide.edu.au /1/lawrence/dh/141en/chapter1.html (дата обращения: 20.11.2016).

12. Бреева T.Н., Хабибуллина Л.Ф. Национальный миф в русской и английской литературе. Казань: ТГГПУ, 2009. 611 с.

\section{THE SYMBOLISM OF PLANTS IN D.H. LAWRENCE'S STORY "ENGLAND, MY ENG- LAND” IN THE CONTEXT OF ENGLISHNESS}

Vestnik Tomskogo gosudarstvennogo universiteta. Filologiya - Tomsk State University Journal of Philology. 2017. 48. 194-201. DOI: 10.17223/19986645/48/14

Liliya F. Khabibullina, Kazan (Volga Region) Federal University (Kazan, Russian Federation). E-mail: fuatovna@list.ru

Keywords: Englishness, D.H. Lawrence, Celtic, Saxon, Norman, vegetative symbols, image of rose.

The article deals with the story "England, My England" (1915) by D.H. Lawrence which plays a prominent role in shaping the idea of Englishness in the literature of the twentieth century, based on the investigations of the 19th century. At that time one of the leading roles here belonged, in the author's opinion, to the study of the diversity of national types in England and their influence on English culture in works by Matthew Arnold, who is considered by many researchers as the founder of the concept of Englishness. In the article the author studies the system of characters and the "plant" symbolism in connection with national types. The analysis of the characters allows to make a conclusion about the author's conception of Englishness. In the story, D.H. Lawrence creates a realistic (the action took place in the period before World War I) and at the same time symbolical picture of life in Britain, where the concept of national character appears in its mythological version with the typical modernist emphasis on the cultural component as an immanent feature of national character. The mythological picture of the world in the story by D.H. Lawrence is created using "vegetative" symbols. Images of plants appear in the story in two ways: first, directly as part of the English countryside, ancient Eng- 
land, embodied in the form of a garden; second, as characteristics of the protagonists through Lawrence's key images of the fictional world - a Tree and a Rose.

The study revealed that the "flower" symbols are used in order to embody the aristocratic values and the values of culture (folklore). The fragility and beauty of the flower represent the disappearance of this system of values. Characters which are connected with the series of "tree" comparisons demonstrate the force and power as the natural procreation of the English land. Implicitly the "flower" and the "tree' symbols are connected with aristocracy and bourgeoisie, but Lawrence does not give strict social characteristics, he prefers the language of symbols. It is important that Lawrence does not consider the bourgeoisie as something alien to England, as an external element. "Tree" symbolism allows to consider this type of people as fruits of the land. The research demonstrates that vegetative symbolism becomes most important in the British national myth, if to understand how important the value of nature and landscape in the culture of England is. This type of symbolization becomes a major feature of the rootedness of the character in the English land. The system of vegetative images creates a mythologized image of England as an ancient land whose secrets remain incomprehensible to us.

\section{References}

1. Ebbatson, R. (2005) An Imaginary England: Nation, Landscape and Literature, 1840-1920. Ashgate.

2. Gikandi, S. (2007) The Ghost of Matthew Arnold: Englishness and the Politics of Culture. Nineteenth-Century Contexts. 29:2-3, June/September 2007. pp. 187-199.

3. Leerssen, J. (2006) Englishness, Ethnicity and Matthew Arnold. European Journal of English Studies. 10:1. April 2006. pp. 63-79.

4. Kelleher, J. (1950) Matthew Arnold and the Celtic Revival. In: Levin, H. (ed.) Perspectives of Criticism. Cambridge, MA: Harvard University Press.

5. Arnold, M. (1867) On the study of Celtic literature. London: Smith, Elder and Co. [Online] Available from:

https:// books.google.co.uk/books?id=hysCAAAAQAAJ\&printsec $=$ frontcover\&hl $=$ ru\# $\mathrm{v}=$ onepage $\& \mathrm{q} \& \mathrm{f}=$ false

6. Sokolova, N. (2004) Viktorianets ob anglichanakh: k probleme osmysleniya natsional'noy identichnosti $\mathrm{v}$ kontekste epokhi [A Victorian about the British: to the problem of understanding national identity in the context of the era]. In: Stulov, Yu.V. (ed.) Problemy identichnosti, etnosa, gendera $v$ kul'ture i literaturakh starogo i novogo sveta [Problems of identity, ethnicity, gender in culture and literature of the old and new world]. Minsk: Propilei.

7. Rivers, B. (2012) Winter-Crack Trees: Botanical Symbolism And D. H. Lawrence's1914 Revisions Of Odour Of Chrysanthemums. Notes and Queries. 59 (3). pp. 411-413. [Online] Available from: https://nq.oxfordjournals.org/content/59/3/411.full.pdf+html?sid=951 faddd-e14c-4d53-a94e153168d38250. (Accessed: 25th October 2016).

8. Antonova, K.N. (2011) Khudozhestvennyy mir prozy D.G. Lorensa 1910-kh godov [The artistic world of D.G. Lawrence's prose of the 1910s]. Abstract of Philology Cand. Diss. St. Petersburg.

9. Abelyan, M.K. (2012) Funktsionirovanie mifologicheskikh obrazov v tvorchestve Deyvida Gerberta Lorensa [The functioning of mythological images in the works of David Herbert Lawrence]. Abstract of Philology Cand. Diss. Voronezh.

10. Lawrence, D.H. (1915) Angliya, moya Angliya [England, My England]. Translated from English by L. Il'inskaya. [Online] Available from: http://lib.ru/INPROZ/CHATER/r_england.txt. (Accessed 25th April 2010).

11. Lawrence, D.H. (1915) England, My England. [Online] Available from: https://ebooks.adelaide.edu.au///lawrence/dh/141en/chapter1.html. (Accessed 20th November 2016).

12. Breeva, T.N. \& Khabibullina, L.F. (2009) Natsional'nyy mif v russkoy i angliyskoy literature [The national myth in Russian and English literature]. Kazan: Tatar State University of Humanities and Education. 